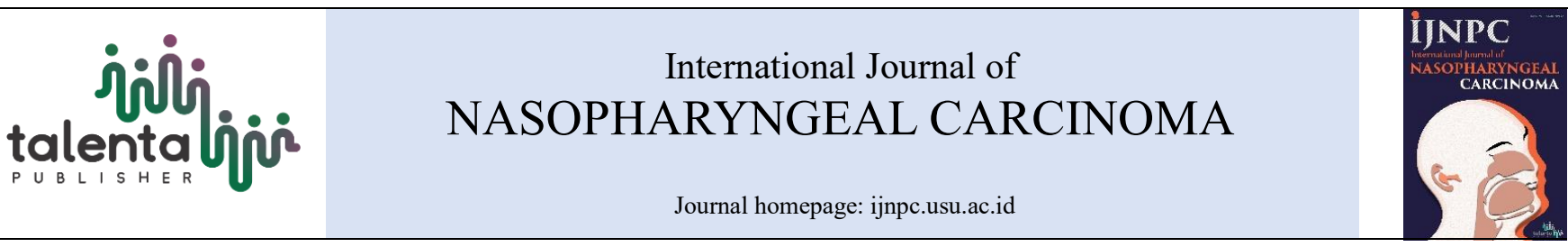

\title{
CHARACTERISTIC OF NASOPHARYNGEAL CARCINOMA IN ACEH 2016-2017
}

\author{
Benny Kurnia $^{1 *}$, Reno Keumalazia Kamarlis ${ }^{2}$, Fera Kamila Kamal ${ }^{3}$ \\ ${ }^{1}$ Oncologyc Division Department of Otorhinolaryngology Head and Neck Surgery, Faculty of Medicine, University of Syiah Kuala, Dr. Zainoel Abidin general \\ hospital, Banda Aceh, Indonesia. \\ ${ }^{2}$ Departement of Pathology Anatomy, Faculty of Medicine, University of Syiah Kuala, Dr. Zainoel Abidin general hospital, Banda Aceh, Indonesia. \\ ${ }^{3}$ Otorhinolaryngology head and neck surgery resident, Faculty of Medicine, University of Syiah Kuala, Dr. Zainoel Abidin general hospital, Banda Aceh, \\ Indonesia
}

\begin{abstract}
Introduction: Nasopharyngeal carcinoma (NPC) is endemic in certain regions of the world, especially in Southeast Asia, and has a poor prognosis. In Indonesia, the recorded mean prevalence are 13.000 yearly new NPC cases, but otherwise little is documented on NPC in Indonesia.

Objectives: We collected all cases of nasopharyngeal carcinoma diagnosed by histopathological examination during the period of 2016-2017 from archives of the registry in the Ear, Nose, and Throat department and Patologi Anatomy laboratory Dr. Zainoel Abidin General Hospital. This research present the basic data of NPC in Aceh according to gender, age, geographic site and WHO histopathology criteria.

Method: All the data were counted by using Microsoft Excel 2016 by grouping it according to the variable that we want to grade. We made it into a table and graphic presentation to explain each item of the variable. Result: We reported 46 cases in the year 2016 and 26 cases in the year 2017 . From a total of 72 patient we found 44 male $(61.1 \%)$ and 28 female $(38.9 \%)$, with a male to female ratio is $1.57: 1$. NPC in Aceh was the most endemic in the Banda Aceh population (15.3\%) followed by Southwest Aceh (12.5\%) as a second one. NPC most frequent to affect patients at the age range 41-60 years $(44.44 \%)$. Here, we found that Undifferentiated NPC is the most frequent histological type (44.4\%). Type I WHO most frequent from the Great Aceh. Type II and Type III WHO we found most frequent from Banda Aceh.

Conclusion: Mostly NPC patients over the world at the old adult age, even all of the age range can be affected by NPC. There are similar histopathological features results here compare to the Southeast Asian country.
\end{abstract}

Article Info

\section{Keywords}

Nasopharyngeal carcinoma, Characteristic, Aceh

\section{*Corresponding author}

Address: Jl.Tgk.Chik Dipineung V no.10 Kp. Pineung, Banda Aceh, Phone Number: +628126928720

e-mail: drbenny_kurnia@yahoo.com

\section{INTRODUCTION}

Nasopharyngeal carcinoma (NPC) is a tumor arising from the epithelial cells that cover the surface and line the nasopharynx. This neoplasm may arise from any site in the nasopharynx, and it is more frequently seen at the lateral wall, from the fossa of Rosenmuller, the recess located medial to the medial crura of the opening of the auditory tympanic tube or the Eustachian tube [1]. The NPC is interesting cancer because of this defined geographic and racial distribution, pointing to genetic, social, and environmental factors in the etiology of this tumor type [2]. It is the most common malignancy of the head and neck and one of the frequent cancer in Indonesia. NPC is five major malignancies in Indonesia as a number four after cervical cancer, breast cancer, and skin cancer [3]. NPC have propensity to metastasize to local, regional, and distant sites [4].

\subsection{Epidemiology}

NPCs have very different ethnic and geographical distributions. Unusual early age onset in high-risk populations implies that early life events may be important. There are recent changes in epidemiology as shown by the decline in NPC incidents [5]. NPC is a rare cancer, accounting for $0.6 \%$ of all cancers diagnosed worldwide in 2012 [4]. Incidence well under 1 per 100.000 persons per year and has a poor prognosis [6]. However, there are areas of the world with endemic disease, and global incidence rates are highest in Southeast Asia (especially southern China), Micronesia/Polynesia, Eastern Asia, and NorthAfrica [2, 4]. Therefore, epidemiologically In Indonesia, the recorded mean prevalence is 13000 yearly new NPC cases [3]. NPC is primarily a tumor of adults with a peak occurrence between 40 and 60 years. The number is 2 to 3 times higher in men than women, and the primary malignant tumor in men, irrespective of geographic location [4]. In this research, we reported NPC in Aceh according to age and gender too as a data to compare with another endemic place around the world.

\subsection{Etiologies}

The etiology of NPC is strongly suggested by the involvement of genetic and environmental factors. Three main etiologies including genetic, environmental, and viral factors are defined here [7]. Unlike other head and neck cancers and epithelial malignancies in general, the unique feature of NPC is a strong relationship with Epstein Barr Virus (EBV). Higher EBV antibody titers were observed in most NPC patients. Latent EBV infection is identified in cancer cells from almost all cases of NPC in endemic areas. The clonal EBV genome is consistently detected in invasive carcinomas and high-level dysplastic lesions. Such observations imply that latent viral infections may have occurred before the expansion of malignant cell clones. A current hypothesis proposes that EBV plays an important role in converting nasopharyngeal epithelial cells to invasive cancer [8]. Traditional foods such as salted fish and other preserved foods containing Volatile nitrosamines are important carcinogenic factors for NPCs [9]. Here, in Aceh salted fish is one of Acheness favorite food until know and it is usually consumed with rice as the main menu.

\subsection{Histopathology}

Nasopharyngeal carcinomas are epithelial neoplasms. Three histopathological types are recognized in the WHO classifications. Type I Keratinizing squamous cell carcinoma (KSCC) with varying degrees of differentiation, type 2 non-keratinizing carcinoma, type 3 undifferentiated carcinoma [10]. The classification of NPC is based solely on light microscopy, with KSCC showing definite evidence of squamous differentiation including intercellular bridges and/or keratinization to a large extent (Picture 1) [7]. Nonkeratinizing carcinoma (NKSCC) comprises solid sheets, irregular islands, dyscohesive sheets and trabeculae of carcinoma intimately intermingled with variable numbers of lymphocytes and plasma cells (Picture 2) [11] 


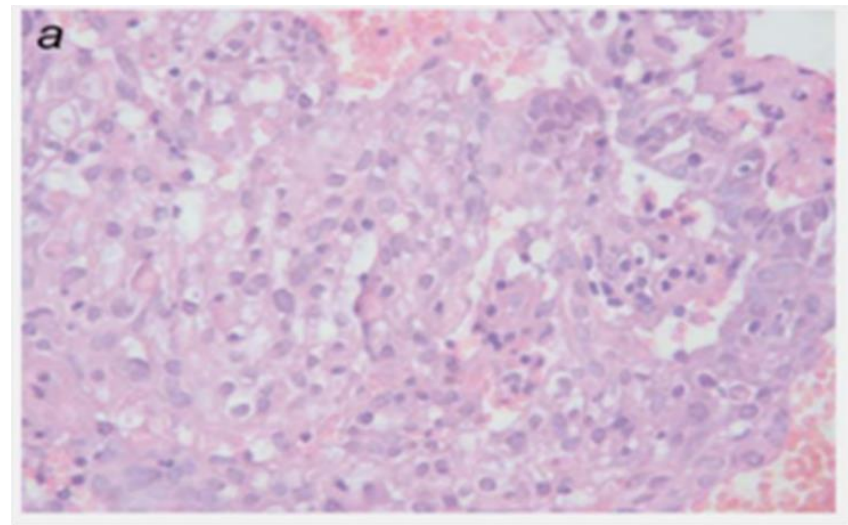

Picture 1. Tumor with keratinization, intercellular bridges

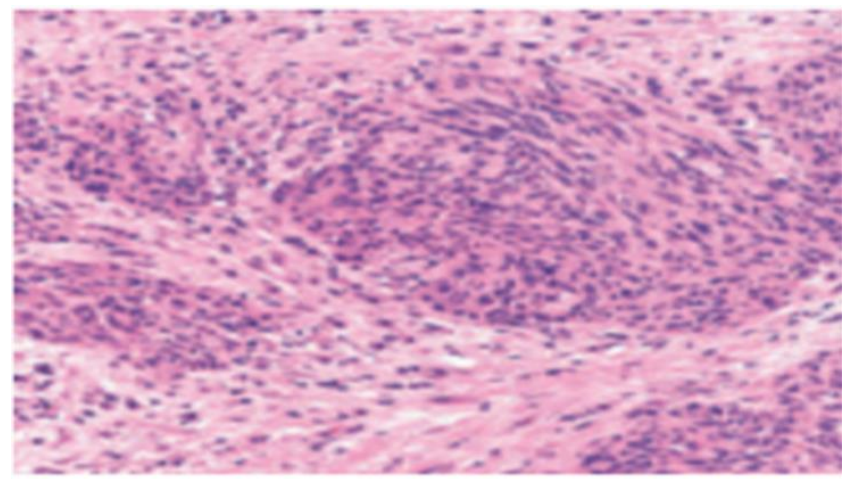

Picture 2. Nonkeratinizing carcinoma, Abundant desmoplastic

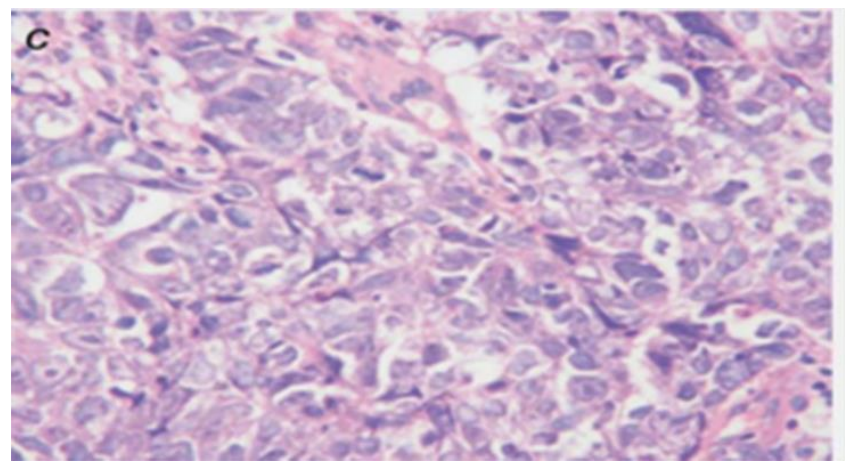

Picture 3. Undifferentiated, syncytial sheet-masses, indistinct cell margins.

Undifferentiated carcinoma should included largeround cell carcinoma, vesicular nucleus cell carcinoma,small cell undifferentiated carcinoma, small cell neuroendocrine carcinoma and part of poorlydifferentiatedsquamous carcinoma [12].

\subsection{Clinical Features}

About half of the patients have multiple symptoms, but $10 \%$ are asymptomatic [13]. Symptoms presented by NPC patients into four categories: (1) symptoms caused by the presence of a tumor mass in the nasopharynx (epistaxis, nasal obstruction, and discharge), (2) symptoms associated with dysfunction of the Eustachian tube (hearing loss), (3) symptoms associated with the superior extension of the tumor (headache, diplopia, facial pain, and numbness), and (4) neck masses [14]. Bony destruction and expansion of the parapharyngeal space may result in a persistent deep-seated headache, and direct invasion of $\mathrm{CN} \mathrm{V}$ can give rise to trigeminal neuralgia. Forward extension into the orbit can produce proptosis and diplopia as well as retroorbital pain. With the invasion of the cavernous sinus, palsies of CNs III, IV and VI can also lead to diplopia or even complete ophthalmoplegia. Involvement of the soft palate and pharyngeal wall may be evidenced by a sore throat or odynophagia. Difficulty in swallowing can also occur through compromise of the lower cranial nerves in the parapharyngeal space when it may be associated with mucosal hypoaesthesia, disturbed taste, palatal incompetence, hemiglossal paralysis and weakness of the muscles innervated by the spinal accessory nerve. Metastatic disease may present as extra-regional lymphadenopathy, bone pain, respiratory symptoms or hepatomegaly. Several paraneoplastic syndromes have been described with NPC including hypertrophic osteoarthropathy [15].

\subsection{Diagnose}

NPC examination includes complete head and neck examination, nasopharyngeal endoscopic examination, biopsy, and MRI covering the base of the skull, face, and the entire neck with or without CT needed for evaluation of bone invasion at the base of the skull. PET/CT and/or chest CT can be used to evaluate distant metastasis, especially for advanced locoregional disease (when the incidence of metastasis is significant) if only chest CT is ordered, bone scanning is required for distant bone metastasis. The Epstein-Barr DNA test (EBV) can also be considered. A multidisciplinary consultation is recommended. Dental evaluation, nutrition, speech and swallowing, and audiology must be carried out as clinically shown. Ophthalmological and endocrinological assessments can also be considered. Human papillomavirus (HPV) infection has been found to be associated with WHO NPC type I in several case reports and case series, but limited data regarding the impact on chemoradiation (CRT) results is still confusing. Therefore, routine testing for HPV on NPC is not recommended by the head and neck NCCN Panel [16].

Table 1. Staging and categories of Nasopharyngeal Carcinoma

\begin{tabular}{|c|c|}
\hline STAGING & CATEGORIES \\
\hline \multicolumn{2}{|l|}{$\mathbf{T}$} \\
\hline $\mathrm{T} 1$ & Nasopharynx, oropharynx, nasal fossa. \\
\hline $\mathrm{T} 2$ & $\begin{array}{l}\text { Tumor with extension to parapharyngeal space and/or infiltration of } \\
\text { the medial pterygoid, lateral pterygoid, and/or prevertebral muscles. }\end{array}$ \\
\hline $\mathrm{T} 3$ & $\begin{array}{l}\text { Tumor invades bony structures of skull base cervical vertebra, } \\
\text { pterygoid structures, and/or paranasal sinuses }\end{array}$ \\
\hline $\mathrm{T} 4$ & $\begin{array}{l}\text { Tumor with intracranial extension and/or involvement of cranial } \\
\text { nerves, hypopharynx, orbit, parotid gland and/or infiltration beyond } \\
\text { the lateral surface of the lateral pterygoid muscle }\end{array}$ \\
\hline $\mathbf{N}$ & CATEGORIES \\
\hline N1 & $\begin{array}{l}\text { Unilateral metastasis, in cervical lymph node(s), and/or unilateral or } \\
\text { bilateral metastasis in retropharyngeal lymph nodes, } 6 \mathrm{~cm} \text { or less, } \\
\text { above the caudal border of the cricoid cartilage. }\end{array}$ \\
\hline N2 & $\begin{array}{l}\text { Bilateral metastasis in cervical lymph node(s), } 6 \mathrm{~cm} \text { or less above } \\
\text { the caudal border of the cricoid cartilage. }\end{array}$ \\
\hline N3 & $\begin{array}{l}\text { Metastasis in cervical lymph node(s) greater than } 6 \mathrm{~cm} \text { in dimension } \\
\text { and/or extension below the caudal border of the cricoid cartilage. }\end{array}$ \\
\hline \multicolumn{2}{|r|}{ STAGE GROUPS } \\
\hline Stage I & T1 N0 M0 \\
\hline Stage II & T1 N1 M0. T2 N0, N1 M0 \\
\hline Stage III & T1, T2 N2 M0. T3 N0, N1, N2 M0 \\
\hline Stage IVA & T4 N0, N1, N2 M0. Any T N3 M0 \\
\hline Stage IVB & Any T Any N M1 ${ }^{[17]}$ \\
\hline
\end{tabular}

\subsection{Therapy}

Patients with T1, N0, M0 nasopharyngeal carcinoma should be treated with definitive radiotherapy alone, including elective RT to the neck. For patients with advanced locoregional NPC (T1, N1-3; T2-T4, any N), enrollment in clinical trials is preferred. The panel recommends concurrent CRT (cisplatin) with adjuvant chemotherapy (cisplatin/5-FU) for NPCs that progress locoregionally. Cisplatin for CRT is recommended for patients without contraindications to the drug because most randomized trials support the use of cisplatin in this setting. When using adjuvant chemotherapy, carboplatin/5-FU adjuvants are a widely accepted choice. For patients with NPC who present with metastatic disease (M1), enrollment in clinical trials is preferred. Other recommended initial therapeutic options include a combination of platinum or CRT systemic therapy regimens, treatment depends on whether the majority of the disease is localized or widespread and whether it is a symptom or presents a clinical risk to the patient. In 2016, pembrolizumab anti-PD-1 antibodies received FDA approval for use in patients with recurrent or metastatic squamous $\mathrm{H} \& \mathrm{~N}$ cancer cells that have developed with platinum chemotherapy [16]. 


\subsection{Purpose}

The research is purposed to present the basic data of NPC in Aceh according to gender, age, geographic site and WHO histopathology criteria so that we could do better things to NPC patient in the future. Observation of NPC cases in our institutions in recent years may be related to increased awareness and application of more advanced treatment options, especially in the Aceh region.

\section{MATERIAL AND METHODS}

We collected all cases of nasopharyngeal carcinoma diagnosed by histopathological examination during the period of 2016-2017 from archives of the registry in the Ear, Nose, and Throat department and Pathology Anatomy laboratory Dr. Zainoel Abidin General Hospital. Besides that, this study is designed to establish the histopathological features of nasopharyngeal carcinoma according to WHO histological classification.

This hospital-based retrospective descriptive-analysis study was done with all patient diagnosed NPC during that time. Inclusion criteria of this study were all cases of nasopharyngeal carcinoma diagnosed by histopathological examination during the period of 2016-2017, and exclusion criteria of this study was all the patients during that time that did not have detail histopathological features based on WHO criteria. In detail, we analyzed and counted the patient based on the age range $(0-20,21-40,41-60,61-80)$ years.

The second result we analyzed the presentation of NPC patient based on gender, male and female. The third category we analyze NPC patient according to geographic features in Aceh. We separated the area according to geographic site, they are 23 area in Aceh, West Aceh, Southwest Aceh, Great Aceh, Aceh Jaya, South Aceh, Singkil, Tamiang, Middle Aceh, Southeast Aceh, East Aceh, North Aceh, Bener Meriah, Bireuen, Gayo lues, Nagan Raya, Pidie, Pidie Jaya, Simeuleu, Banda Aceh, Langsa, Lhokseumawe, Sabang, and Subulussalam.

The last category we analyzed the data according to histopathologic features based on WHO category, Keratinizing SCC (type I), nonkeratinizing SCC (type II) and Undifferentiated Carcinoma (type III). We compared each other data by analyzed geographic site according to each WHO criteria. All the data were counted by using Microsoft Excel 2016 by grouping it according to the variable that we want to grade. We made it into a table and graphic presentation to explain each item of a variable.

\section{RESULT}

\subsection{Gender Characteristic}

From the data we collected, we found that out of a total of 72 patients, gender distribution among NPC cases showed 44 men versus 28 women. In our case, we found the same dominance, with $61.1 \%$ of male cases and $38.9 \%$ of female cases producing a ratio of 1.57: 1 shown in the tables and graphs below. (table 2 and graphic 1).

Table 2. Gender Characteristic of NPC Patients

\begin{tabular}{lcc}
\hline \multicolumn{1}{c}{ Gender } & Total & $\%$ \\
\hline Male & 44 & $61.1 \%$ \\
Female & 28 & $38.9 \%$ \\
\hline Total & $\mathbf{7 2}$ & $\mathbf{1 0 0 . 0 \%}$ \\
\hline
\end{tabular}

Graphic 1. Gender Characteristic of NPC patients

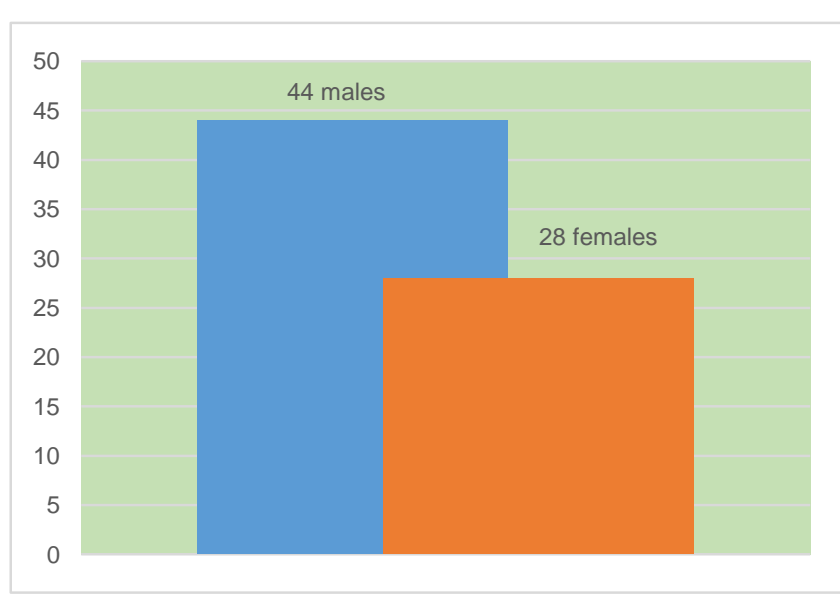

\subsection{Age Characteristic}

The age characteristic of NPC patients in our hospital most frequent to affect patients at the age range $41-60$ years $(44.44 \%)$, followed by age range $61-80$ years $(23.61 \%), 21-40$ years $(20.83 \%)$, besides that we found 8 patients $(11.11 \%)$ cases NPC in Aceh at the age $0-20$ years with 13 years old patient was the younger one. The range age will be shown in the table and graphic below (table 3 and graphic 2).

Table 3. The Age Characteristic of NPC Patients

\begin{tabular}{lcc}
\hline Age ( years ) & Total & $\%$ \\
\hline $0-20$ & 8 & $11.11 \%$ \\
$21-40$ & 15 & $20.83 \%$ \\
$41-60$ & 32 & $44.44 \%$ \\
$61-80$ & 17 & $23.61 \%$ \\
\hline Total & $\mathbf{7 2}$ & $\mathbf{1 0 0 . 0 0 \%}$ \\
\hline
\end{tabular}

Graphic 2. The Age Characteristic of NPC Patients

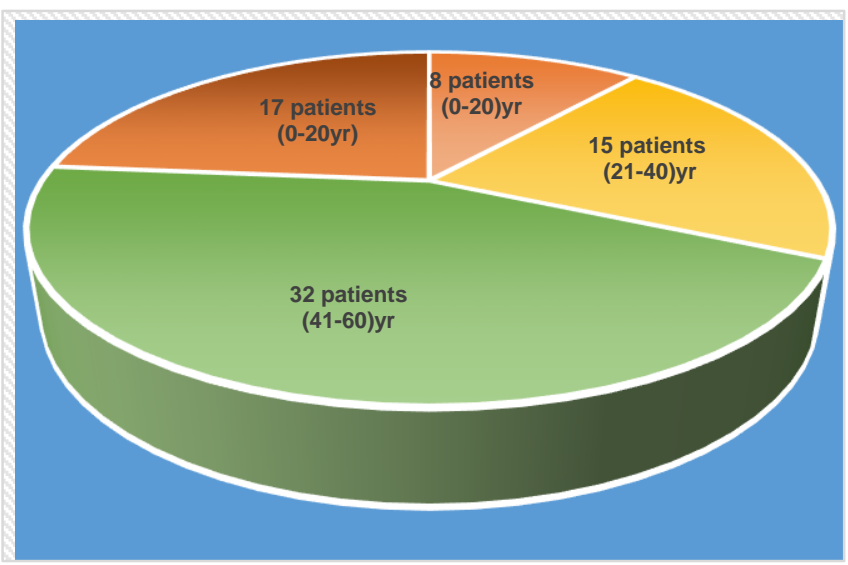

\subsection{Geographic Site}

According to geographic site, NPC in Aceh was the most endemic in the Banda Aceh population (15.3\%) followed by Southwest Aceh (12.5\%), Central Aceh (9.7\%), Bireun and Pidie Jaya (8.3\%) Lhokseumawe and West Aceh (6.9\%), Great Aceh and South Aceh (5.6\%), North Aceh, Langsa, West Aceh,Nagan Raya, Pidie, and Simeulue (2.8\%). The data will be shown in table 4 and graphics 3 .

Table 4. NPC Patient According to Geographic Site

\begin{tabular}{lcr}
\hline \multicolumn{1}{c}{ Geographic site } & Total & $\%$ \\
\hline West Aceh & 5 & $6.9 \%$ \\
Southwest Aceh & 9 & $12.5 \%$ \\
Great Aceh & 4 & $5.6 \%$ \\
South Aceh & 4 & $5.6 \%$ \\
Singkil & 1 & $1.4 \%$ \\
Tamiang & 1 & $1.4 \%$ \\
Central Aceh & 7 & $9.7 \%$ \\
North Aceh & 2 & $2.8 \%$ \\
Banda Aceh & 11 & $15.3 \%$ \\
Bireuen & 6 & $8.3 \%$ \\
Gayo Lues & 1 & $1.4 \%$ \\
Langsa & 2 & $2.8 \%$ \\
Lhokseumawe & 5 & $6.9 \%$ \\
West Aceh & 2 & $2.8 \%$ \\
Nagan Raya & 2 & $2.8 \%$ \\
Pidie & 2 & $2.8 \%$ \\
Pidie Jaya & 6 & $8.3 \%$ \\
Simeulue & 2 & $2.8 \%$ \\
\hline Total & $\mathbf{7 2}$ & $\mathbf{1 0 0 . 0 \%}$ \\
\hline
\end{tabular}


Graphic 3. NPC Patient According to Geographic Site

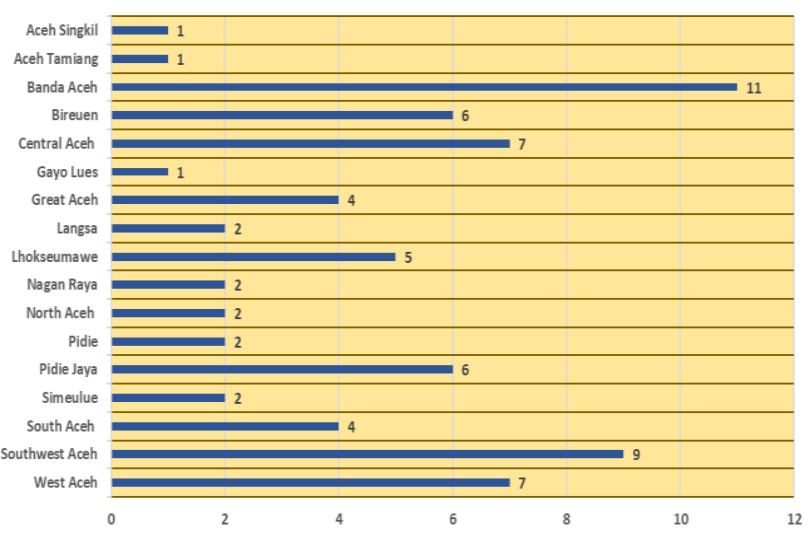

\subsection{Histopathologic Features}

According to WHO criteria, we found that Undifferentiated Carcinoma $(44.4 \%)$ is the most common histopathological features here, followed by Nonkeratinizing Squamous Cell Carcinoma (33.3\%) and Keratinizing Squamous Cell Carcinoma is the last one $(22.3 \%)$. the detail data will be shown below (table 5 and graphic 4).

Table 5. Histopathologic Features of NPC Patients

\begin{tabular}{lcc}
\hline \multicolumn{1}{c}{ Histopathology } & Total & $\boldsymbol{\%}$ \\
\hline Keratinizing Squamous Cell Carcinoma & 16 & $22.2 \%$ \\
Non-Keratinizing Squamous Cell Carcinoma & 24 & $33.3 \%$ \\
Undifferentiated Carcinoma & 32 & $44.4 \%$ \\
\hline Total & $\mathbf{7 2}$ & $\mathbf{1 0 0 . 0 \%}$ \\
\hline
\end{tabular}

Graphic 4. Histopathologic Features of NPC Patients

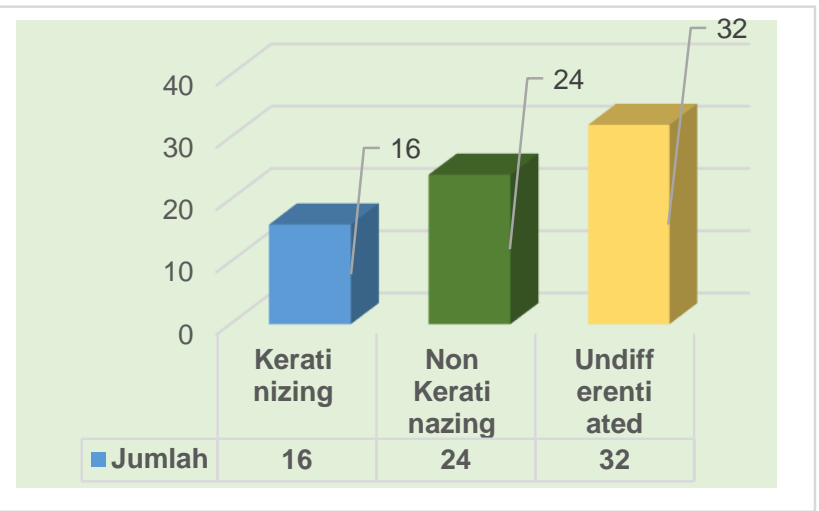

\subsection{Histopathologic Type According to Geographic Site}

We continued the study by analyzed geographic site of NPC patient according to WHO criteria and then we found that type I WHO (Keratinizing Squamous Cell Carcinoma) most frequent from the Great Aceh (18.8\%), followed by Southwest Aceh and West Aceh (12.5\%), and from Aceh Tamiang, Central Aceh, Banda Aceh,Bireun, Langsa, Pidie Jaya and Lhokseumawe we found (6.3\%). The detail data will be shown in table and graphic below (table 6 and graphic 5)

Table 6. Type I WHO According to Geographic Site

\begin{tabular}{lcc}
\hline \multicolumn{1}{c}{ Geographic site } & Total & $\boldsymbol{\%}$ \\
\hline Southwest Aceh & 2 & $12.5 \%$ \\
Great Aceh & 3 & $18.8 \%$ \\
Tamiang & 1 & $6.3 \%$ \\
Central Aceh & 1 & $6.3 \%$ \\
Banda Aceh & 1 & $6.3 \%$ \\
Bireuen & 1 & $6.3 \%$ \\
Langsa & 1 & $6.3 \%$ \\
Lhokseumawe & 1 & $6.3 \%$ \\
West Aceh & 2 & $12.5 \%$ \\
Pidie Jaya & 1 & $6.3 \%$ \\
Simeulue & 2 & $12.5 \%$ \\
\hline Total & $\mathbf{1 6}$ & $\mathbf{1 0 0 . 0 \%}$ \\
\hline
\end{tabular}

Graphic 5. Type I WHO According to Geographic Site

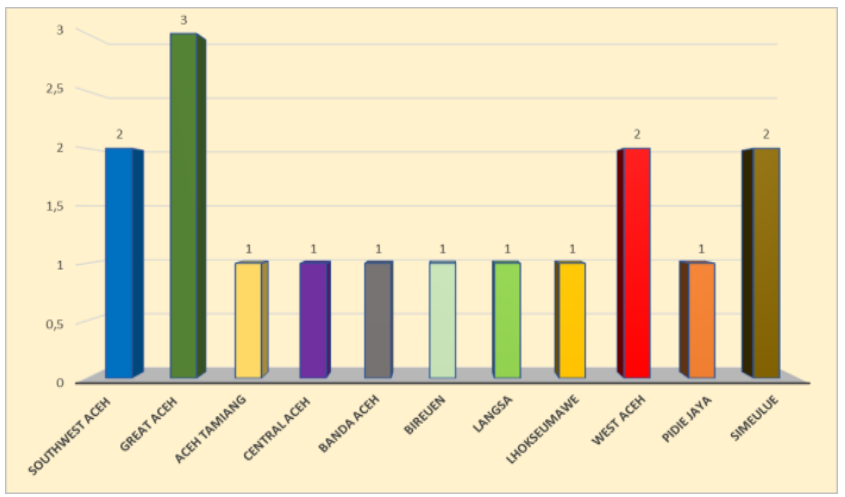

Type II WHO (Non Keratinizing Squamous Cell Carcinoma) we found most frequent from Banda Aceh (16.7\%), followed by West Aceh, Southwest Aceh and Bireuen (12.5\%), Central Aceh, North Aceh, and Pidie Jaya (8.3\%), then Great Aceh, South Aceh, Singkil, Langsa and Lhokseumawe (4.2\%). The detail data will be shown below (table 7 and graphic 6)

Table 7. Type II WHO According to Geographic Site

\begin{tabular}{lcc}
\hline \multicolumn{1}{c}{ Geographic site } & Total & $\%$ \\
\hline West Aceh & 3 & $12.5 \%$ \\
Southwest Aceh & 3 & $12.5 \%$ \\
Great Aceh & 1 & $4.2 \%$ \\
South Aceh & 1 & $4.2 \%$ \\
Singkil & 1 & $4.2 \%$ \\
Central Aceh & 2 & $8.3 \%$ \\
North Aceh & 2 & $8.3 \%$ \\
Banda Aceh & 4 & $16.7 \%$ \\
Bireuen & 3 & $12.5 \%$ \\
Langsa & 1 & $4.2 \%$ \\
Lhokseumawe & 1 & $4.2 \%$ \\
Pidie Jaya & 2 & $8.3 \%$ \\
\hline Total & $\mathbf{2 4}$ & $\mathbf{1 0 0 . 0 \%}$ \\
\hline
\end{tabular}

Graphic 6. Type II WHO According to Geographic Site

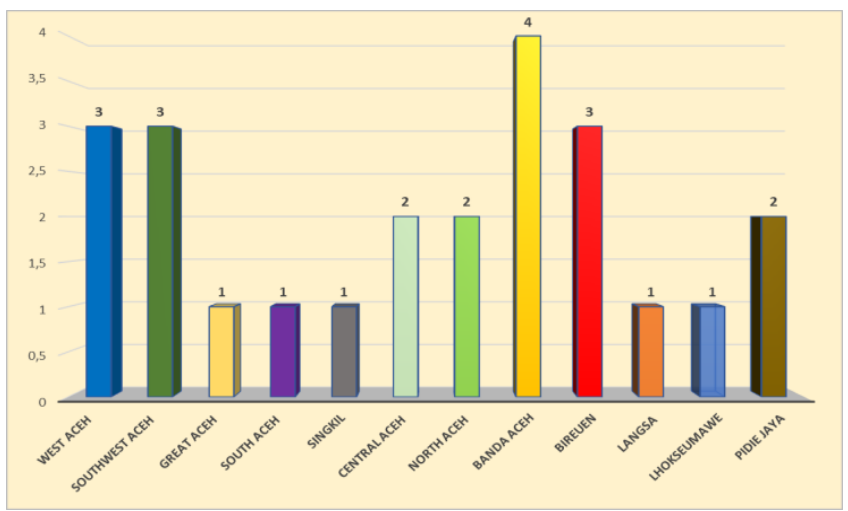

Type III WHO (Undifferentiated Carcinoma) we found most frequent from Banda Aceh (18.8\%), followed by Southwest Aceh and Central Aceh (12.5\%), South Aceh, Lhokseumawe and Pidie Jaya (9.4\%), West Aceh, Nagan Raya, Pidie, Bireuen (6.3\%), and from Gayo Lues (3.1\%). The detail data will be shown below (table 8 and graphic 7).

Table 8. Type III WHO According to Geographic Site

\begin{tabular}{lcc}
\hline \multicolumn{1}{c}{ Geographic site } & Total & $\boldsymbol{\%}$ \\
\hline West Aceh & 2 & $6.3 \%$ \\
Southwest Aceh & 4 & $12.5 \%$ \\
South Aceh & 3 & $9.4 \%$ \\
Central Aceh & 4 & $12.5 \%$ \\
Banda Aceh & 6 & $18.8 \%$ \\
Lhokseumawe & 3 & $9.4 \%$ \\
Nagan Raya & 2 & $6.3 \%$ \\
Pidie & 2 & $6.3 \%$ \\
Pidie Jaya & 3 & $9.4 \%$ \\
Bireuen & 2 & $6.3 \%$ \\
Gayo Lues & 1 & $3.1 \%$ \\
\hline Total & $\mathbf{3 2}$ & $\mathbf{1 0 0 . 0 \%}$ \\
\hline
\end{tabular}


Graphic 7. Type III WHO According to Geographic Site

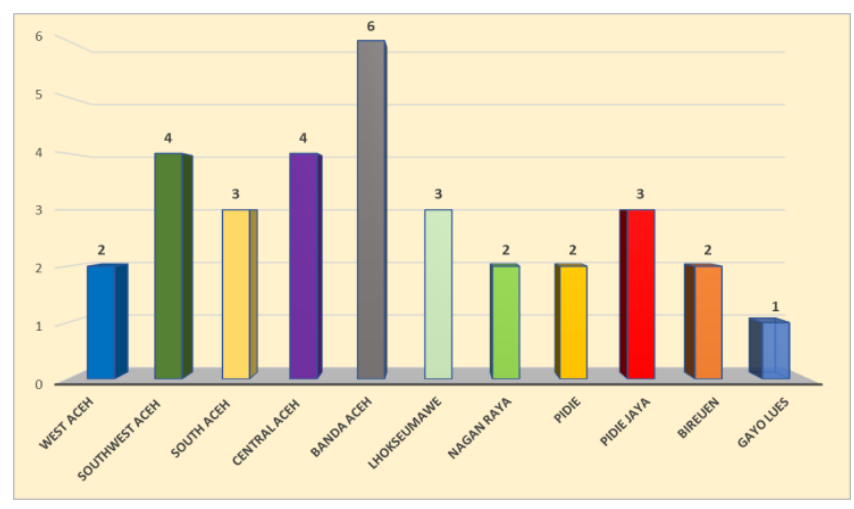

\section{DISCUSSION}

We presented our data about the incidence of NPC in Aceh that diagnosed by histopathological examination during the period of 2016-2017 from archives of the registry in the Ear, Nose, and Throat department and Patologi Anatomy laboratory Dr. Zainoel Abidin General Hospital. From the data, it is clear that Aceh is one of the regions in Indonesia with many NPC incidence, about almost 50 newly NPC cases on a year. Importantly, upperclass Aceh patients may seek specialized treatment in neighboring countries like Malaysia, so that they did not include our data. Observing NPC cases at our institution in recent years may be due to an increase in referrals rather than actual events. This might be related to increasing awareness and implementing more advanced treatment options, especially in the Aceh region. NPC is ranked fourth among cancer in men in Indonesia. Patients are generally referred to in the final stages. Overall care is complex, not cost-effective, and places a significant socio-economic burden on patients and their families. Adequate data for follow-up from the referral center is usually not available. Registration of patients with NPC is, in many cases, not digital and therefore inadequate. Patients are often referred to the hospital at the final stage, which has major weaknesses in their prognosis [3].

\subsection{The Gender Characteristic}

From the data we collected, we found that out of a total of 72 patients, gender distribution among NPC cases showed 44 men versus 28 women. In our case, we found the same dominance, with $61.1 \%$ of men and $38.9 \%$ of female cases producing 1.57:1. From the literature, gender distribution among cases of NPCs from the Ear, Nose and Throat department in the Hospital Dr. Cipto Mangunkusumo showed that $70.4 \%$ of men and $29.6 \%$ of women had a ratio of $2.4: 1$. The ratio of men: women was relatively stable for many years [3]. From the Department of Radiation Oncology, Taizhou Hospital, Wenzhou Medical College, Taizhou, Zhejiang, China gender characteristic of NPC patients are male: female ratio, 2.1:1 [18]. From the journal of The prevalence and prevention of nasopharyngeal in China, there is a common feature across populations demonstrating that the incidence rate of NPC in men is higher than in women, with a ratio of $2: 3$ [5]. Overall the world and Indonesian gender characteristic of NPC we found that NPC has mostly appeared at the male than the female with median rate male three times more affected than woman similar to our region. Until now we not found any study yet that explain for the detail why NPC always more affected in the male the woman. We hope later there will be explained in another research.

\subsection{Age Characteristic}

The age characteristic of NPC patients in our hospital most frequent to affect patients at the age range 41-60 years $(44.44 \%)$, followed by age range $61-80$ years $(23.61 \%), 21-40$ years $(20.83 \%)$, besides that we found 8 patients $(11.11 \%$ ) cases NPC in Aceh at the age $0-20$ years with 13 years old patient was the younger one. In the literature, the overall peak of events was described at the age of 50 to 60 years. In high-risk areas, such as Hong Kong, the incidence of NPC in each sex has increased sharply since the age of 20 years and also reached a plateau between the ages of 40 and 60 years. In China, most cases occur in the fifth and sixth decades of life.

In contrast, there is a bimodal distribution in North Africa, with a major peak incidence of around 50 years, similar to a single peak observed in China, and a small peak in people aged between 10 and 25 years. This form of adolescence accounts for about $20 \%$ of patients and has specific clinical and biological features. In Indonesia, a steady increase was observed long before age 45 , beginning in early adolescence. The age distribution for NPC is bimodal in some populations of North America and the Mediterranean region, with the peak incidence at 10 to 20 years and the second at 40 to 60 years. Children under 16 years represent $1 \%$ to $2 \%$ of all patients with NPC in China, 2.4\% at United Kindom, $7.12 \%$ in Turkey, $10 \%$ in the United States, $12 \%$ in Israel, $13 \%$ in Kenya, $14.5 \%$ in Tunisia, and $18 \%$ in Uganda [3]. Our data on the overall incidence of NPC did not differ significantly between the literature. Mostly NPC patients over the world at the old adult age, even all of the age range can be affected by NPC, not except teenagers and kids like we found $8 \%$ here. The incidence of juvenile NPCs can reflect genetic vulnerability and/or exposure to young age to cocarcinogens in the environment. It is unfortunate if young patients are treated for the latest illness and unfortunately become victims of deadly diseases at a young age. In conclusion, there is no doubt that this disease, affecting individuals aged 40 to 60 years and those under 30 years. Therefore, early detection with simple and adorable techniques, such as nasopharyngeal brushing, blood investigations and adjuvant laboratory examinations for periodic assessment of the status of specific disease markers, is the most important.

\subsection{Geographic Site}

According to geographic site, NPC in Aceh was the most endemic in the Banda Aceh population (15.3\%) followed by Southwest Aceh (12.5\%), Central Aceh (9.7\%), Bireun and Pidie Jaya (8.3\%) Lhokseumawe and West Aceh (6.9\%), Great Aceh and South Aceh (5.6\%), North Aceh, Langsa, West Aceh,Nagan Raya, Pidie, and Simeulue (2.8\%) Banda Aceh, Central Aceh, Southwest Aceh regions of high incidence. There are many capital cities in Aceh geography, so that makes us difficult to see which region that most affected a lot. That is very important to see detail region characteristic to analyze what makes a special thing in a region that affected by NPC more than another. Although most patients in our study are from Banda Aceh the Capital Town in Aceh province whereas the Zainoel Abidin general hospital is in here, it became clear that other geographical groups in the entire Acehnese population were also influenced by NPCs. Because of that other areas must be explored more intensively. Worldwide, NPC patients are mostly influenced by ethnic Chinese. Therefore, NPCs are a major problem in Aceh and are not only related to Chinese genetics. Chinese migrants have been shown to maintain a high incidence of NPC even in the next generation, showing strong genetic control [3]. Our data reveals that this disease does not follow Chinese demographics and does not seem to be influenced by Chinese genetics even though large populations of Chinese descent live in Aceh and its surroundings, and despite this, high NPC incidents with Chinese origin are shown in neighboring countries.

\subsection{Histopathologic Features}

According to WHO criteria, we found that Undifferentiated Carcinoma (44.4\%) is the most common histopathological features here, followed by Non-keratinizing Squamous Cell Carcinoma (33.3\%) and Keratinizing squamous Cell Carcinoma is the last one $(22.3 \%)$. According to WHO classification, NPC is histopathologically divided into three categories of keratinizing squamous cell carcinoma (WHO type I), non-keratinized squamous cell carcinoma (WHO type II), and undifferentiated carcinoma (WHO type III). NPC WHO type III is the most common form of NPC in Southeast Asia and other high-incidence areas and is most closely associated with EBV infection. WHO type I tumors can also be associated with EBV in endemic areas, but usually not in nonendemic areas, where they result from negative tobacco and alcohol and EBV abuse [3]. There are similar histopathological features here compared to other Southeast Asian countries. Because WHO type III is most closely related to EBV infection, we suspect that here, there is something related to EBV as well. For the future, we need more detailed research to find out the characteristics of EBV in our region. 


\subsection{Histopathologic Type According to Geographic Site}

We continued the study by analyzed geographic site of NPC patient according to WHO criteria and then we found that type I WHO (Keratinizing Squamous Cell Carcinoma) most frequent from the Great Aceh (18.8\%), followed by Southwest Aceh and West Aceh (12.5\%), and from Aceh Tamiang, Central Aceh, Banda Aceh,Bireun, Langsa, Pidie Jaya and Lhokseumawe we found (6.3\%). Type II WHO (Non Keratinizing Squamous Cell Carcinoma) we found most frequent from Banda Aceh (16.7\%), followed by West Aceh, Southwest Aceh and Bireuen (12.5\%), Central Aceh, North Aceh, and Pidie Jaya (8.3\%), then Great Aceh, South Aceh, Singkil, Langsa and Lhokseumawe (4.2\%). Type III WHO (Undifferentiated Carcinoma) we found most frequent from Banda Aceh (18.8\%), followed by Southwest Aceh and Central Aceh (12.5\%), South Aceh, Lhokseumawe and Pidie Jaya (9.4\%), West Aceh, Nagan Raya, Pidie, Bireuen (6.3\%), and from Gayo Lues (3.1\%). From the data, we can make a conclusion that in Great Aceh whereas more frequent type I WHO related to tobacco and alcohol abuse more than in Banda Aceh, even in another side alcohol, in general, is not our habit not like tobacco that we can find in almost area in Aceh. Another result that Banda Aceh has more type II and III WHO is related to EBV infection. For the future, we need to find more about risk factor include environmental and viral factor as a factor that affected NPC more detail in Aceh.

\section{CONCLUSION}

From the data we collected, we found that out of a total of 72 patients, gender distribution among NPC cases showed man dominated than woman. The aging characteristic of NPC patients in our hospital most frequent to affect patients at the age range 41-60 years (44.44\%). According to geographical sites, NPCs in Aceh are the most endemic in the Banda Aceh population (15.3\%), but other geographical groups in the entire Aceh population are also influenced by NPCs. According to WHO criteria, we found that Undifferentiated Carcinoma (44.4\%) is the most common histopathological features here. Because of WHO type III is most closely associated with EBV infection, for the future, we need more detail research to know about EBV characteristic in our region. To know the related between WHO category and geographic detail, we need another research about risk factor whether viral or environmental in Aceh.

\section{REFERENCE}

[1] Bailey BJ, Johnson JT, Newlands SD. Head \& neck surgery--otolaryngology: Lippincott Williams \& Wilkins; 2006.

[2] Ji M, Yu Y, Cheng W. Nasopharyngeal carcinoma: early detection by serological screening and clinical examination. Chin J Cancer. 2011;30(2):120-3.

[3] Adham M, Kurniawan AN, Muhtadi AI, Roezin A, Hermani B, Gondhowiardjo $\mathrm{S}$, et al. Nasopharyngeal carcinoma in Indonesia: epidemiology, incidence, signs, and symptoms at presentation. Chinese journal of cancer. 2012;31(4):185.

[4] Colevas AD, Yom SS, Pfister DG, Spencer S, Adelstein D, Adkins D, et al NCCN guidelines insights: head and neck cancers, version 1.2018. Journal of the National Comprehensive Cancer Network. 2018;16(5):479-90.

[5] Cao S-M, Simons MJ, Qian C-N. The prevalence and prevention of nasopharyngeal carcinoma in China. Chinese journal of cancer. 2011;30(2):114.

[6] Hsu W-L, Chen J-Y, Chien Y-C, Liu M-Y, You S-L, Hsu M-M, et al Independent effect of EBV and cigarette smoking on nasopharyngeal carcinoma: a 20-year follow-up study on 9,622 males without family history in Taiwan. Cancer Epidemiology and Prevention Biomarkers. 2009;18(4):1218-26.

[7] Ji X, Zhang W, Xie C, Wang B, Zhang G, Zhou F. Nasopharyngeal carcinoma risk by histologic type in central China: impact of smoking, alcohol and family history. International journal of cancer. 2011;129(3):724-32.

[8] Wang WY, Twu CW, Chen HH, et al. Plasma EBV DNA clearance rate as a novel prognostic marker for metastatic/recurrent nasopharyngeal carcinoma. Clin Cancer Res 2010;16:1016-1024

[9] Jia, Wei Hua, et al., Traditional Cantonese diet and nasopharyngeal carcinoma risk: a large-scale case-control study in Guangdong, China, BMC Cancer, 2010:2

[10] Brockstein, Bruce et al., Head and Neck Cancer, Kluwer Academic Publisher, Cancer Treatment and Research, 2002:277

[11] Barnes, Leon, et al., World Health Organization Classification of Tumours, Pathology \& Genetics Head and Neck Tumours, IARCPress Lyon, 2005:87-88

[12] Wei, Kuang Rong, et al., Histopathological Classification of Nasopharyngeal Carcinoma, Asian Pacific J Cancer Prev, 2011:1145
[13] Cardesa, Antonio, Slodwag, Pieter, Pathology of the head and neck, Springer-Verlag Berlin Heidelberg 2006:56

[14] Tabuchi, Keiji, et al., Early Detection of Nasopharyngeal Carcinoma, Hindawi Publishing Corporation International Journal of Otolaryngology, 2011:2

[15] Evans, Peter H Rhys et al., Principles and Practice of Head and Neck Oncology an imprint of the Taylor \& Francis Group, 2006:342

[16] NCCN, 2018, Clinical Practice Guideline in Oncology Cervical Cancer, Version 1. 2018, National Comprehensive Cancer Network, Inc

[17] Pan, Jian Ji, et al., Proposal for the 8th Edition of the AJCC/UICC Staging System for Nasopharyngeal Cancer in the Era of Intensity-Modulated Radiotherapy, Wiley Online Library (wileyonlinelibrary.com), 2016:551

[18] Wang Wei et al., Clinical Study Of The Necessity Of Replanning Before The 25th Fraction During The Course Of Intensity-Modulated Radiotherapy For Patients With Nasopharyngeal Carcinoma, International Journal of Radiation Oncology Biol. Phys., Vol. 77, No. 2010:618 